\title{
Democracy and its Impact on Economic Development in Sub-Saharan Africa
}

\author{
Sanji Walters Mudoh", Chang Seek Lee ${ }^{* *}$ \\ Dep. of Lifelong Education, Graduate School, Hanseo University ${ }^{*}$ \\ Dept. of Child and Adolescent Welfare, Hanseo University ${ }^{* *}$ \\ 아프리카 사하라 이남의 민주정치와 경제발전의 관계 연구 \\ 산지 월터스 무도 ${ }^{*}$, 이창식 ${ }^{* *}$ \\ 한서대학교 대학원 평생교육학과 ${ }^{*}$ 한서대학교 아동청소년복지학과 ${ }^{* *}$
}

\begin{abstract}
This study aimed to clarify the relationship which exists between democracy and economic development within Sub-Saharan Africa. It strived to bring out a comprehensive analysis of the reasons why the pace of democratization is slow within this region and why until present date, there are just patches of real democracies there. The work also focuses on the reasons why despite democratic movements, economic growth rates have remained lagging behind average until of recent that, and some few countries have emerged to join the list of fastest growing economies in the world. The study further highlights the unique path of Sub-Saharan Africa democratization process should follow since it does not possess the various factors that favored the democratization processes of most developed countries. In order to obtain the objectives, previous studies and statistical data published by official institutes were analysed by using contents analysis methods. Lastly, it proceeds to explain the important role that democracy plays in inclusive economic growth.
\end{abstract}

Key Words : Democracy, Economic Development, Sub-Sahara, Africa

요 약 이 연구는 아프리카 사하라 이남의 민주정치와 현재 경제발전의 관계를 규명하는 것으로 목적으로 하였다. 특히 사하라 이남 지역에서 민주화 속도가 늦은 이유와 현재까지 민주정치에 따른 문제의 원인을 종합적으로 분석하 였다. 그리고 민주정치 운동에도 불구하고 경제성장율이 평균 이하인 이유와 일부 국가들이 빠른 경제성장 궤도에 오른 이유도 초점을 두었다. 더 나아가서 다른 선진국들의 민주화과정에 적합한 요인들을 가지지 못하였기 때문에 이 지역의 민주정치가 독자적인 노선을 추구해야 하는 이유에도 초점을 두었다. 이러한 분석을 위하여 기존의 논문 및 보고서를 중심으로 내용분석하였다. 끝으로 경제성장에서 민주주의 역할을 제언하였다.

주제어 : 민주정치, 경제성장, 사하라 이남, 아프리카

\section{Introduction}

The study addresses three main issues: the

Received 25 June 2014, Revised 26 July 2014

Accepted 20 August 2014

Corresponding Author: Chang Seek Lee(Hanseo University)

Email: lee1246@hanmail.net

ISSN: $1738-1916$ importance of democracy to economic growth of the sub-region, why, until recently, democracy did not yield the desired economic growth within the region,

(C) The Society of Digital Policy \& Management. All rights reserved. This is an open-access article distributed under the terms of the Creative Commons Attribution Non-Commercial License (http://creativecommons.org/licenses/by-nc/3.0), which permits unrestricted non-commercial use, distribution, and reproduction in any medium, provided the original work is properly cited. 
and how to enable democracy to boost further economic growth within the area. Real democratic movement was introduced in Sub-Saharan Africa in 1989. In fact, democratization plays a role in fostering economic growth. However, in the case of Sub-Saharan Africa, a great deal of time has been taken for it to trigger development within some parts of the region. This is due to the fact that this region generally lacks the other factors which are needed to interact with democracy in order to stimulate economic growth and true democracy. These factors include good legal systems, free markets, cautious government expenditures, and a vibrant middle class. The analysis below would thus help to illuminate the above charges.

Democracy is very important to economic development because it helps to structure a government with the ability to deliver economic development with people's human rights at heart. When democracy goes along with economic development, citizens are confident to have a share of the proceeds of development. In democratic governments, people are made to have a sense of belonging as they are empowered to demand and shape good policies, express grievances ,seek justice, and hold leaders and the private sector accountable for their stewardships. Legally stable economies will favor both internal and foreign investors. It is then obvious that since dictators, like some African Heads of states who have been in power for more than 30 years, are susceptible to succession crisis and fear of the future, they often change the constitution to suit their position in power. Actually there has been a great deal of debate on democracy and development which will be clearly examined in this work. Some authors, like Lipset [1], suggest that economic development triggers change which promotes democracy. This means when people acquire wealth via economic development, they tend to seek out freedom via democracy .This therefore implies that poor people who are not empowered by wealth have no power to seek freedom via democracy. Hence, it is economic development which triggers democracy, not democracy fostering development. Unlike Lipset, the new institutionalists, such as North and Thomas, North and North [2], suggest that, good institutions favor economic development and vice versa. Also, Burnside and Dollar [3] suggested that "aid is only growth enhancing in environments blessed with good institutions". In response to the institutionalists' arguments, donors started offering aid packages only to countries with good governance.

However, experience reveals that countries with different leadership types can develop economically. It all depends on the determination of the leaders, the citizens of the country, and the external influences surrounding them. What makes democracy very important is that it helps to encourage people make their own choice of leaders, and, in addition, protect the excesses of non-benevolent leaders with a good rule of law .Constitutional monarchies may also have a good rule of law, but the greatest advantages of democratic government are that there is freedom, a fair distribution of income, and a decentralization of power. Above all, democracy is the best government for every country which has the interests of its citizens at heart. However, sadly, its results have not yet been positive in many Sub-Saharan Africa countries. This is due to the fact that the electorate is poor and weak; therefore, they need to be empowered to be able to withstand the democratization process .Attempts by donor countries to empower the electorate are being frustrated by embezzlers who never allow the money to empower the poor grassroots people. Cameroon is a typical example of such a vicious cycle of poverty. In Sub-Saharan Africa, the few countries which have actually allowed their electorate to be empowered by aid money through the virtues of good governance have democratically and economically advanced. These include Ghana, Tanzania, Kenya, Nigeria, the Benin Republic, and Mauritius. 


\section{The relationship and economic growth}

\subsection{Why is it taking long for democracy to yield economic growth within Sub- Saharan Africa?}

As a matter of facts, most of these countries have poor governments mare with very high corruption and embezzlement rates. The elites who find themselves in administrative or political positions use manipulating techniques to advance their own personal goals. The leaders build up tyrannical mechanisms with a democratic outlook. Only citizens can understand this, for foreign observers cannot break through the myths. Most of the leaders become despots and share privileges with other elites who help them to maintain their status. During elections, these elites assist in rigging, intimidating, and bribing the electorate to vote for the incumbent president. Furthermore, workers are promised higher positions and unemployed graduates are promised jobs if they campaign in favor of the incumbent presidents. According to Ludgwid Von Mises [4], "There is no more dangerous menace to civilization than a government of incompetent, corrupt, or vile men. The worst evils which mankind ever had to endure were inflicted by bad governments. The state can be and has often been in the course of history the main source of mischief and disaster". For these reasons, democratization transitions have produced political instability, ethnic conflicts, and poor economic out comes within most of the states. For instance, Robert D. Kaplan [5] states that, "if a society is not in reasonable health, democracy can be not only risky but disastrous". Fareed Zakaria [6] points out that, "although democracy has in many ways opened up African politics and brought people liberty, it has also produced a degree of chaos and instability that actually made corruption and lawlessness worse in many countries". However, after a series of political crisis, some countries have made significant steps in democracy and economic development. These include Tanzania, Ghana, Kenya, Nigeria, Mauritius, and the Benin Republic. According to the White House [7], "Africa's economies are among the fastest growing in the world, with technological changes sweeping across the continent and offering tremendous opportunities in banking ,medicine ,politics ,and in business ." Looking at the situation of Cameroon, attempts into democracy led to a total weakening of the governing institutions and an increase in human suffering and misery when compared to the past.

However, according to Bertelsmann Shiftung [8], "Cameroon has by [and] large made minimal if any progress in terms of political and economic transformation during the assessment period." Looking at democracy, the ruling government during the July 2007 legislative and municipal elections only took advantage of voters' apathy and the fact that the main opposition party Social Democratic Front (SDF) refused to participate in the election. The ruling party, the Cameroon Democratic Party, won two-thirds of the parliamentary seats and used this majority in parliament to change the country's constitution so that the president should be eligible to stand for another 7 year term of office in the 2011 election. Now in 2014, President Paul Biya of Cameroon has been in power for 30 years as he finally won the presidential election of 2011. As revealed by Bertelmann Shiftung [9], "Cameroon's economic structure and performance do not meet the criteria for a socially responsible market democracy, and do not constitute a frame work that allows citizens adequate freedom of choice. Growth rates have now been positive for a long period of time, but individual opportunities are heavily restricted, and the lower strata do not profit from growth". From 2007/8 Cameroon was ranked $150^{\text {th }}$ on the Human Development Index(HDI) and in 2012, it ranked $131^{\text {st }}$. There has been little advancement in industrialization, with most people living a subsistence life style. Thus, chances of attaining millennium development goals are 
very slim. To prove that wealth is important for the advancement of democracy in Sub-Saharan Africa, a careful study of western democracies reveals that a majority of them gained a somewhat wealthy middle class through Enlightened or Benevolent despots of the $18^{\text {th }}$ centurybeforedemocratization. Typical examples are Frederick II of Prussia, Catherine II of Russia, Maria Theresa and Joseph II of Austria, Carlos III of Spain, and Napoleon Bonaparte of France. Even in contemporary times, emerging economies still reflect this phenomenon. A good example is South Korea. President Park Jung Hee, who catalyzed South Korean development, was a benevolent despot .It was only after a middle class had been created by his development efforts that democracy functioned effectively.

\subsection{What are the consequences of democracy within Sub-Saharan Africa on global immigration and refugee problems?}

Due to the political upheavals which resulted from the struggle for democracy in many countries in Sub-Saharan Africa, many people were victimized. Some died, others were physically incapacitated, and many fled into other countries causing immigration and refugee problems. Even at the moment, youths are still fleeing from those countries which still practice fake democracy or countries with poor governance performance. The truth is that, because of this fake democracy, a new group of extremely rich people have evolved (the elite who help to maintain the incumbent president in power) who enjoy enormous privileges .They help to widen the income gap between themselves and the common man by means of corruption and embezzlement. This is not the type of new class that is needed in Africa. What is needed to make good governance is a vibrant middle class. Youths from such poor governance performing countries now become immigration problems for other countries, especially the United States, Europe, and the vibrant economies of Asia .Some even die in the course of crossing through the Sahara desert into Spain.

\subsection{How can democracy boost further economic development within Sub- Saharan Africa?}

After carefully examining the above analyses, in terms of a transition into democracy, Sub-Saharan Africa countries have a missing link .That is the means to create a vibrant middle class. These countries must not follow the same path of the western world, for stopping their democratization processes to move back into benevolent despotism does not make any sense. Indeed, democracy is the only government which allows for a fair treatment of its citizens.

In my humble opinion, the empowerment of the electorate and clean and fair elections are the key points of Sub-Saharan Africa democracy. Efforts should be geared towards the fact that the despots of Africa who use democracy as an umbrella often intentionally keep the electorate in a desperate corner so that they can yield to their fake promises of jobs and distribution of soap, rice, salt, and money during election time.

The electorate can be empowered via foreign aid in the form of finance, technical expertise, education, and machinery. However, for this aid to actually empower the electorate, their governments must cooperate by instituting good governance. The donors should also follow up on the progress of the projects. Governments should also put in emphasis on science and technology. At the end of the day, good governance or democratic governments attract investors. The key point is that these countries must understand that aid is a source of taking off, not an end to development. Therefore, aid money should be maximized to enhance sustainable development. Good governance is the key to this type 
of development since aid donors are primarily attracted to countries with good governance. As President Barack Obama said in Ghana, "Africa doesn't need strong men, it needs strong institutions" [10]. These institutions, therefore, must be those with good rules of law, respect for human rights, and accountable to their citizens. Obama has launched many initiatives since he took office in order to help achieve a balance between democracy and development within Sub-Sahara Africa. He is involved in strengthening democratic institutions and boosting broad-based economic growth through trade and investment. He encourages good accountability and a deep commitment to the rules of law. Africa is the focus of three presidential development initiatives: The Global Health Initiative Feed the Future, and The Global Climate Change Initiative.

My fear is that, if the United States and other aid donors are working only with high governance performing countries, there would be no balanced development in Sub-Saharan Africa. Most Francophone African countries would be left behind in this democratic and economic development race since they are the worst governance performers. In my opinion, I would recommend that the United States and international bodies like the United Nations see that entire countries meet the required levels of good governance performance. These bodies should also remove constraints to international trade so that manufactured goods from Africa can compete in international markets.

In the course of researching, I came up with a kind of democratic and economic development organization model which, when introduced in Sub-Saharan Africa, can speed up economic development. I call this movement "Unite and Make it Work". Experience reveals that in most Sub-Saharan countries there is a rural urban exodus especially by the youthful population, which is the economically active group. Also, a good number of the educated population who cannot have jobs are moving abroad . The economic situations of the rural areas are deteriorating, giving room to primate cities. The truth is that sustainable development cannot be achieved if rural development is not taken into consideration. In Sub-Saharan Africa, the rural areas lack good toilet systems, well roofed houses, good bridges and roads, adequate electricity, clean water supplies, good agricultural techniques, etc. "Unite and Make it Work" would not only be a development project organization but also a struggle for a better livelihood for both individuals and the entire society. The administration of the organization would be based on democratic principles with precautions in place to have only the most innovative leaders. Via this organization, people would have to be taught not to work only for themselves but for their villages and nations as a whole. Through a network of this organization, governments and aid donors could assist in sponsoring and providing technical expertise to develop rural areas. Through this same network, conferences, workshops, seminars, and symposia could be held to educate the masses on how to carry on activities diligently.

\section{Concussion}

From the strength of the above analysis it can be generally concluded that, even though there exist some patches of democracies, democracy has not yet yielded the desired economic development expected by Sub-Saharan Africa. This is because the kind of democracy practiced by most states is not real. The reason being that, the factors facilitating smooth functioning of democracy are absent. These factors include a good rule of law, vibrant middle class, careful government consumption and powerful electorate. Though different types of governments can enhance economic development, democracy is good in that it promotes inclusive growth. In democratic governments, 
people are made to have a sense of belonging as they are empowered to demand and shape good policies, express grievances, seek justice, and hold leaders and the private sector accountable for their stewardships. Since this is absent in most Sub-Saharan countries, the limited economic development achieved is not enjoyed by the lower classes which constitute a bulk of the masses hence political instabilities. Politically and legally stable economies will favor both internal and foreign investors for economic development.

\section{REFERENCES}

[1] Lipset, Seymour Martin, Some Social Requisites of Democracy: Economic Development and Political Legitimacy, 1995.

[2] Helpman, E., Ed., Institutionsand Economic Performance. Princeton N.J., Princeton University Press, 2008.

[3] Burnside, C, and Dollar, Aid, Growth and policies, American Economies Review 90(4), (pp. 839-878), 2000.

[4] http://news.bbc.co.uk/2/hi/africa/8145762.stm

[5] Kaplan, Robert D., The Coming Anarchy: Shattering the Dreams of the Post-Cold War. New York: Random House, 2000.

[6] Zakaria, F., The future of Freedom: In Illiberal Democracy at Home and Abroad. New York: Norton, 2003.

[7] The White House Washington. U.S Strategy Toward Sub-Saharan Africa, 2012. http://iipdigital.usembassy.gov/st/english/texttrans/ 2012/06/201206147448.html\#axzz0BCloJkxq [accessed $13^{\text {th }}$ December 2013]

[8] Stiftung, Bertelsmann, Cameroon Country Report .Gutersloh: Bertelsmann Stiftung, 2010. http://www.bti-project.org/fileadmin/Inhalte/report s/2010/pdf/BTI\%202010\%20Cameroon.pdf

[9] Stiftung, Bertelsmann, Cameroon Country Report .Gutersloh: Bertelsmann Stiftung, 2010
http://www.bti-project.org/fileadmin/Inhalte/report s/2010/pdf/BTI\%202010\%20Cameroon.pdf [Accessed5 ${ }^{\text {th }}$ May2014]

[10] BBC News (July 11 ${ }^{\text {th }}$ 2009) Obama Speaks of Hopes for Africa. http://news.bbc.co.uk/2/hi/africa/8145762.stm

\section{산지 월터스 무도(Sanji Walters Mudoh)}

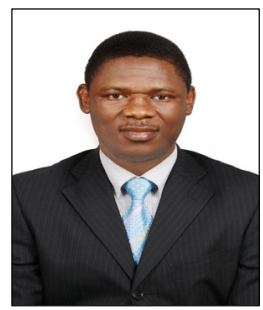

- 2014년 2월 현재 : 한서대학교 평생교육학과 박사과정

- 관심분야 : 다문화교육, 평생교육

·E-Mail : sanwally5@gmail.com

이 창 식(Lee, Chang Seek)

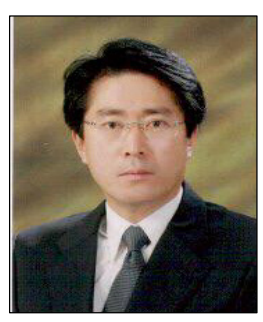

· 1984년 2월 : 서울대학교(교육학석 사)

-1991년 4월 : University of the Philippines (Ph.D.)

- 1993년 2월 현재 : 한서대학교 아 동청소년복지학과 교수

- 관심분야 : 다문화교육, 기부

•E-Mail : lee1246@hanmail.net 